\title{
Economic Identity of Different Generations of Russians*
}

\author{
Victoria Mukha \\ Department of Sociology, Law and Human Resources \\ Kuban State Technological University \\ Krasnodar, Russia \\ E-mail: v.mukha@bk.ru \\ Olga Brizhak \\ Department of Institutional Economics \\ State University of Management \\ Moscow, Russia \\ Department of Economic Theory and Investment \\ Kuban State Technological University \\ Krasnodar, Russia \\ E-mail: brizhak71@mail.ru
}

\author{
Elena Klochko \\ Department of management \\ Kuban State Agrarian University \\ Krasnodar, Russia \\ E-mail: magadan.79@mail.ru
}

\author{
Daria Vakhrameeva \\ Department of Sociology, Law and Human Resources \\ Kuban State Technological University \\ Krasnodar, Russia \\ E-mail: dv.vakh@yandex.ru
}

\begin{abstract}
The article is devoted to the study of economic identity of different age groups of Russians. The authors presented a theoretical analysis of the category of "economic identity", described the characteristics of the structure and content of this socio-psychological phenomenon. The cognitive component, affective component and behavioral component of economic identity of different generations of Russians were examined on the basis of a secondary analysis of the results of nationwide surveys.
\end{abstract}

Keywords-social identity; economic identity; economic selfesteem; financial situation; generational analysis; intergenerational differences

\section{INTRODUCTION}

At present, the economic status of a person becomes its most important characteristic, and the achievement of material well-being occupies a leading place among life goals. People's perceptions of their financial situation have a significant impact not only on their everyday economic behavior and relationships with others, but also largely determine the system of their value orientations, their life strategies and worldview. In Russia at this historical moment, representatives of the following major generations coexist: Generation M "silent generation" (born 1923-1943), Generation BB "Baby Boomers" (born 1943-1963), Generation X (born 1963-1983), Generation Y (b. 19832003), Generation $Z$ (born after 2003+). The identification orientations and values of these generations of Russians were formed in different historical eras, in different state entities (USSR and Russia). In this regard, the traditional

*Project: The study was carried out as part of the RFBR grant No. 19011-00834 "Identification matrices of four generations of Russians in modern Russia."

\begin{abstract}
"generational conflict" may be exacerbated by contradictions in the socio-economic sphere, the mismatch of economic claims, perceptions of wealth and poverty, etc. Economic identity can act as a regulator of social behavior of individual, interpersonal and intergroup relations, which in turn determines the attention to generational analysis of this socio-psychological phenomenon.
\end{abstract}

\section{SUBJECT AREA ANALYSIS}

One of the first to introduce the concept of economic identity was W. James. He links this type of identity with the result of the individual referring himself to a particular property group. Further, various aspects of economic identity were considered mainly within the framework of economic psychology when studying individual ideas of people about wealth and poverty, social inequality, a person's perception of his own wealth. In Russian science, the individual components of economic identity were studied, as a rule, in the context of the study of individual groups (professional, ethnic, family, etc.), but without attention to the holistic structure of this phenomenon. Separately, it should be noted a number of works that have made significant contributions to the study of economic identity. In particular, the work of V.A. Khashchenko, where the author presented a detailed theoretical analysis of economic identity as a structural component of an individual's economic identity [1]. Among the applied developments, it is necessary to note the standardized program for the study of the economic and psychological characteristics of the personality, which was developed by A.L. Zhuravlev and N.A. Crane [2]. The program defines such criteria as the attitude to wealth, material well-being, income, the direction of use of funds, entrepreneurial activity, individual values and the moral and 
self-esteem are determined by the high economic claims of certain social groups" [4].

In general, an analysis of the theoretical foundations and empirical criteria allows us to conclude that the basis for the formation of the economic identity of a person is a subjective model of her personal well-being. This model includes the following elements: cognitive (social representations, knowledge, reflection); conative (motivational-needful states of consciousness - readiness, intentions, preferences, interests, stereotypes); emotional (feelings, assessments, feelings). Within the framework of this article, it is not possible to analyze all of the above elements, therefore, we select only some of them.

\section{RESEARCH METHODS}

To analyze the structure of the economic identity of Russians, the authors conducted a secondary analysis of the results of the all-Russian polls of the POF:

- The weekly survey "FOMnibus" July 13-14, 2019 (53 subjects of the Russian Federation, 104 settlements, 1,500 respondents) [5];

A number of experimental studies have established that empirical indicators of economic identity at the personal level are "attitude to property; attitude to oneself as an economic subject, including the person's self-image, economic well-being, economic claims, type of locus of control of economic self-awareness; attitude to living conditions" [3]. It should be noted that there is a difficulty in the objective measurement of this phenomenon, in view of the psychosocial nature of the formation of economic identity. Awareness of one's economic status of a person occurs through correlation of the objective economic situation of a person with the system of his internal attitudes, ideas about welfare. Determining the features of the functioning of the economic identity of Russians N.I. Chernobrovkina notes that "the self-esteem of the economic status of Russians is inversely proportional to their economic claims, which creates a duality in the economic identity of the population: low material security and, as a result, low
- The weekly survey "FOMnibus" July 28, 2017 (53 constituent entities of the Russian Federation, 104 settlements, 1,500 respondents) [6];

- The weekly survey "FOMnibus" October 7-8, 2017 (53 subjects of the Russian Federation, 104 settlements, 1,500 respondents) [7];

- The weekly survey "FOMnibus" July 27-28, 2019 (53 subjects of the Russian Federation, 104 settlements, 1,500 respondents) [8].

\section{RESULTS AND ITS DISCUSSION}

Consider the individual components of economic identity, based on data obtained by POF. So one of the components of economic identity is economic self-esteem, that is, the individual's idea of his own economic status ("Table I").

TABLE I. SELF-ASSESSMENT OF FinANCIAL SituAtion, \% [5]

\begin{tabular}{|c|c|c|c|c|c|}
\hline \multirow{2}{*}{$\begin{array}{l}\text { Do you have a good } \\
\text { or bad financial } \\
\text { situation now? }\end{array}$} & \multirow{2}{*}{$\begin{array}{c}\text { The } \\
\text { population as } \\
\text { a whole }\end{array}$} & \multicolumn{4}{|c|}{ Age } \\
\hline & & 18-30 years old & $31-45$ years old & 46-60 years old & over 60 years old \\
\hline good & 11 & 21 & 10 & 4 & 9 \\
\hline average & 60 & 63 & 59 & 60 & 59 \\
\hline bad & 28 & 16 & 30 & 35 & 31 \\
\hline difficult to answer & 1 & 0 & 1 & 2 & 1 \\
\hline Total & 100 & 100 & 100 & 100 & 100 \\
\hline
\end{tabular}

Subjective economic status is a cognitive component of economic identity. This component is based not only on a person's assessment of his real well-being, but also based on his expected level in accordance with the economic claims of the individual. Members of all age groups evaluate their financial situation mainly as "average", while the rating "good" prevails in the age group from 18 to 30 years $(21 \%)$.
Members of older generations do not so positively assess this criterion; in a group from 46 to 60 years old, $35 \%$ of respondents rated their financial situation as bad.

Economic identity determines a person's satisfaction with his real material situation. Satisfaction with material well-being becomes an indicator of the affective component 
question of understanding what "prosperous life" is ("Table II") and a question of respondents' assessment of their own life as prosperous ("Table III"). of economic identity. There was no direct question about satisfaction with financial situation in the data of the analyzed opinion polls, but this indicator can be used indirectly for other questions of the questionnaire: it is a

TABLE II. REPRESENTATIONS OF A PROSPEROUS LIFE, \% [6]

\begin{tabular}{|c|c|c|c|c|c|}
\hline \multirow{2}{*}{$\begin{array}{l}\text { How do you understand the } \\
\text { expression "well-being"? What } \\
\text { does it mean for you personally? }\end{array}$} & \multirow{2}{*}{$\begin{array}{c}\text { The } \\
\text { population } \\
\text { as a whole }\end{array}$} & \multicolumn{4}{|c|}{ Age } \\
\hline & & 18-30 years old & $31-45$ years old & $46-60$ years old & over 60 years old \\
\hline $\begin{array}{l}\text { Wealth, material well-being, lack } \\
\text { of need }\end{array}$ & 54 & 56 & 53 & 53 & 55 \\
\hline $\begin{array}{l}\text { Your health and the health of loved } \\
\text { ones }\end{array}$ & 14 & 10 & 13 & 17 & 16 \\
\hline Stability, confidence in the future & 12 & 10 & 16 & 13 & 10 \\
\hline Family, children, grandchildren & 10 & 13 & 10 & 10 & 5 \\
\hline Peace, lack of war & 10 & 7 & 6 & 9 & 19 \\
\hline Stable work & 8 & 9 & 10 & 9 & 4 \\
\hline
\end{tabular}

The answers to this question indicate that Russians associate well-being primarily with the material component.
The most popular answer (54\% of Russians chose it): a prosperous life is material wealth and lack of need.

TABLE III. Self-ESTEEM OF THE WELL-BeING OF His LifE, \% [6]

\begin{tabular}{|c|c|c|c|c|c|}
\hline \multirow{2}{*}{$\begin{array}{c}\text { In general, do you consider } \\
\text { your life prosperous or } \\
\text { dysfunctional? }\end{array}$} & \multirow{2}{*}{$\begin{array}{c}\text { The } \\
\text { population } \\
\text { as a whole }\end{array}$} & \multicolumn{4}{|c|}{ Age } \\
\hline & & 18-30 years old & 31-45 years old & 46-60 years old & over 60 years old \\
\hline Prosperous & 74 & 83 & 75 & 66 & 72 \\
\hline Dysfunctional & 22 & 14 & 20 & 30 & 23 \\
\hline Difficult to answer & 4 & 4 & 5 & 4 & 5 \\
\hline
\end{tabular}

Self-esteem of well-being varies in age groups: respondents older than 46 years more often assess their life as dysfunctional, while respondents under 30 overwhelmingly give the opposite assessment.

The moral component of economic identity includes moral assessments of poverty and wealth. Poverty and wealth as complex socio-economic phenomena are expressed not only in the shortage or excess of economic resources that provide a certain standard of living, but also in a special lifestyle, behavioral norms and perception stereotypes transmitted from generation to generation. This subjective perception of wealth and poverty is the basis of subjective economic well-being - "the basic construction of economic consciousness, expressing a person's personal attitude to his present and future material well-being" [9]. Thus, the impact of the subjective relationship of wealth and poverty affects not only a person's life, his behavior, life satisfaction, psychological well-being, but also on the adoption of economic decisions.

A POF survey conducted in 2017 showed a mixed attitude of Russians towards poverty and wealth ("Table IV" and "Table V").

TABLE IV. ATtitude TO WeALth, \% [7]

\begin{tabular}{|c|c|c|c|c|c|}
\hline \multirow{2}{*}{$\begin{array}{l}\text { Do you agree with the fact that } \\
\text { wealth usually spoils people and } \\
\text { contributes to the development } \\
\text { of their worst qualities? }\end{array}$} & \multirow{2}{*}{$\begin{array}{c}\text { The } \\
\text { population } \\
\text { as a whole }\end{array}$} & \multicolumn{4}{|c|}{ Age } \\
\hline & & $18-30$ years old & $31-45$ years old & 46-60 years old & over 60 years old \\
\hline I agree & 63 & 55 & 61 & 63 & 73 \\
\hline I do not agree & 31 & 41 & 34 & 28 & 21 \\
\hline Difficult to answer & 6 & 4 & 6 & 8 & 6 \\
\hline
\end{tabular}

The desire for wealth is no longer considered something shameful, examples of luxurious life are demonstrated through the media and social networks and become the subject of claims of a certain part of the population. But respondents' estimates of wealth are not so straightforward. About two thirds of the respondents indicate that "wealth usually spoils people" ("Table IV"). Young people, to a lesser extent than older generations, share this opinion, but 
The survey also showed a negative perception of poverty ("Table V"). even in the younger age group the indicators of negative perception of wealth are still high.

In general, we can say that among representatives of all generations a critical attitude towards the rich is preserved and reproduced.

TABLE V. RELATION TO POVERTy, \% [7]

\begin{tabular}{|l|l|l|l|l|l|}
\hline $\begin{array}{l}\text { Do you agree that poverty usually } \\
\text { spoils people and contributes to the } \\
\text { development of their worst } \\
\text { qualities? }\end{array}$ & \multirow{2}{*}{$\begin{array}{c}\text { The population as } \\
\text { a whole }\end{array}$} & \multicolumn{5}{|c|}{ Age } \\
\cline { 3 - 7 } & & $\mathbf{1 8 - 3 0}$ years old & $\mathbf{3 1 - 4 5}$ years old & $\mathbf{4 6 - 6 0}$ years old & over 60 years old \\
\hline I agree & 38 & 28 & 37 & 44 & 45 \\
\hline I do not agree & 56 & 67 & 59 & 50 & 46 \\
\hline Difficult to answer & 6 & 5 & 4 & 6 & 9 \\
\hline
\end{tabular}

The opinion that poverty contributes to the development of the worst qualities in people is shared by $38 \%$, but the majority rejects it. At the same time, representatives of the young generation agree with the opinion about the negative impact of poverty much less often than older people.

We can conclude by correlating two questions about the impact of poverty and wealth, which, according to Russians, it is wealth that contributes to the development of worse qualities, while poverty does not spoil people.
Next, we turn to the behavioral component of economic identity. Among the behavioral reactions associated with economic self-identification, conflict and avoidant behavior are distinguished on the one hand, and productive on the other. In this article, we will consider productive behavior as an example of Russians' perceptions of the potential for doing business.

But first, we turn to the way the population sees a change in their material well-being in the near future ("Table VI").

TABLE VI. ASSESSMENT OF CHANGES In FinANCIAL Position, \% [5]

\begin{tabular}{|l|l|l|l|l|l|}
\hline $\begin{array}{c}\text { Do you think that in the coming year your } \\
\text { financial situation will improve, worsen, } \\
\text { or hardly change? }\end{array}$ & $\begin{array}{c}\text { The population as a } \\
\text { whole }\end{array}$ & $\begin{array}{c}\text { 18-30 years } \\
\text { old }\end{array}$ & $\begin{array}{c}\mathbf{3 1 - 4 5} \text { years } \\
\text { old }\end{array}$ & $\begin{array}{c}\text { 46-60 years } \\
\text { old }\end{array}$ & \begin{tabular}{c} 
over 60 years old \\
\cline { 2 - 6 }
\end{tabular} \\
\hline will improve & 22 & 36 & 23 & 16 \\
\hline will get worse & 18 & 9 & 15 & 26 \\
\hline practically will not change & 39 & 37 & 40 & 23 \\
\hline difficult to answer & 21 & 18 & 22 & 37 \\
\hline
\end{tabular}

As can be seen from the data presented, the age group from 46 to 60 years old perceive the next year with the least optimism, while young people are more optimistic about the change in the economic situation. Of course, this attitude affects the willingness to certain behavioral reactions that can lead to a change in economic status (change of job, opening your own business, investing, etc.). For the implementation of entrepreneurial activity, it is important not only to have entrepreneurial potential, but also to be able and willing to activate it. ("Table VII")

TABLE VII. The DesiRE To BeCOME AN ENTREPRENEUR, \% [8]

\begin{tabular}{|l|l|l|l|l|l|}
\hline $\begin{array}{l}\text { Do you personally want or would } \\
\text { not want to become an } \\
\text { entrepreneur and start your own } \\
\text { business? (The question was asked } \\
\text { by everyone except entrepreneurs, } \\
\text { 95\% of respondents answered) }\end{array}$ & \multirow{2}{*}{$\begin{array}{c}\text { The population as } \\
\text { a whole }\end{array}$} & \multicolumn{2}{|l|}{ Age } \\
\hline I would like to & 25 & 18-30 years old & $\mathbf{3 1 - 4 5}$ years old & $\mathbf{4 6 - 6 0}$ years old & over 60 years old \\
\hline I would not want & 66 & 49 & 30 & 16 & 5 \\
\hline difficult to answer & 4 & 41 & 56 & 78 & 92 \\
\hline
\end{tabular}

The younger generation (from 18 to 30 years old) replied that they would like to become entrepreneurs and start their own business to a greater extent from all the Russians surveyed (49\%). Among older generations, the desire to start an independent business is much less: $78 \%$ of Russians aged
46-60 years and 92\% of Russians over 60 years old would not want to start their own business. Entrepreneurial intentions can turn into real actions. 
TABLE VIII. ENTREPRENEURIAL INTENTIONS, \% [8]

\begin{tabular}{|c|c|c|c|c|c|}
\hline \multirow{2}{*}{$\begin{array}{l}\text { Are you planning to do business in the } \\
\text { next 3-5 years, in the more distant } \\
\text { future, or do you have no specific } \\
\text { plans? (The question was asked for } \\
\text { those who would like to become an } \\
\text { entrepreneur and start their own } \\
\text { business, 25\% of respondents } \\
\text { answered) }\end{array}$} & \multirow{2}{*}{$\begin{array}{c}\text { The population } \\
\text { as a whole }\end{array}$} & \multicolumn{4}{|c|}{ Age } \\
\hline & & $18-30$ years old & $31-45$ years old & 46-60 years old & $\begin{array}{c}\text { over 60 years } \\
\text { old }\end{array}$ \\
\hline Yes, in the next 3-5 years & 8 & 18 & 11 & 3 & 1 \\
\hline Yes, in the more distant future & 5 & 14 & 4 & 1 & 0 \\
\hline I have no definite plans & 12 & 17 & 15 & 10 & 4 \\
\hline difficult to answer & 0 & 0 & 0 & 1 & 0 \\
\hline
\end{tabular}

As shown in "Table VIII", representatives of the young generation (18-30 years old) prevail among those who plan to start entrepreneurial activity in the next $3-5$ years - $18 \%$. But it should be noted that $17 \%$ of respondents aged 18-30 years also noted that they did not have any specific plan. Most respondents from older generations also say that they do not have specific plans to start their own business. It should also be noted that often the potential willingness and desire to start an entrepreneurial activity does not translate into real actions and does not lead to the start of a business.

\section{CONCLUSION}

The analysis allows us to draw some conclusions. Economic identity as an element of an individual's economic identity is formed in the process of economic identification and on the basis of a subjective welfare model. The cognitive component of economic identity, which is represented by subjective economic status, is assessed by the Russians as "average," and tends to decrease in assessment depending on the age of the respondents. The affective component, which is characterized by satisfaction with the financial situation, varies in age groups: respondents over 46 years old more often assess their life as dysfunctional, while respondents under 30 overwhelmingly give a positive assessment. The behavioral component, which is considered in this article on the example of Russians' perception of the potential for entrepreneurial activity, is most pronounced among the younger generation, and older generations are generally not ready and would not like to engage in entrepreneurial activity.

\section{REFERENCES}

[1] Khashchenko V.A. Economic identity of a person: psychological determinants of formation // Psychological Journal. 2004. Vol. 25. No. 5. Pp 32-49.

[2] Zhuravlev A. L. Economic self-determination: theory and empirical research. M.: Publishing House "Institute of Psychology RAS", 2007. $480 \mathrm{p}$.

[3] Terekhova T.A. An experimental study of the economic identity of a person // Psychology in Economics and Management. 2014. No. 1. Pp 33-39.
[4] Chernobrovkina N.I. Indicators of economic identity of the region's population at micro and macro levels // Social and humanitarian knowledge. 2016. No. 12. Pp 56 - 63.

[5] POF. The dynamics of the financial situation of Russians. URL: https://fom.ru/Ekonomika/14233 (accessed September 12, 2019).

[6] POF initiative: a study of the well-being of Russians. URL: https://fom.ru/TSennosti/14244 (accessed September 12, 2019).

[7] About the poor, the rich and the difference in income. URL: https://fom.ru/Ekonomika/13815 (accessed September 12, 2019).

[8] Conditions for entrepreneurship in Russia. URL: https://fom.ru/Ekonomika/14237 (accessed September 12, 2019).

[9] Khashchenko V. Psychology of economic well-being. M .: Publishing House "Institute of Psychology RAS", 2012. 432 p. 